\title{
Boško Buha i Pavlik Morozov: novi (jugoslavenski / sovjetski) čovjek u tijelu malenoga dječaka
}

\author{
DANIJELA LUGARIĆ VUKAS \\ Odsjek za istočnoslavenske jezike i književnosti, \\ Filozofski fakultet Sveučilišta u Zagrebu
}

\begin{abstract}
Pavlik Morozov i Boško Buha prvi su mladi junaci-žrtve u sovjetskoj, odnosno jugoslavenskoj kulturi, koji se mogu promatrati kao modeli za izgradnju ideje o novome čovjeku. Dva "nova čovjeka" u tijelima dvojice dječaka na različitim razinama, od vizualne reprezentacije do artikulacije životnih putova u tekstovima kulture, iznenađujuće nalikuju jedan drugome. Obojica su bili hrabri maloljetnici, porijeklom iz provincija, stradali su zbog svoje odanosti ideološkim režimima te su postali idoli-žrtve koje su političke elite iskoristile za političku manipulaciju. Međutim, dok je Pavlik Morozov poslužio kao idealni model za artikulaciju različitih sovjetskih ideja o novome čovjeku, image Boška Buhe posljedica je posvema drukčijeg političkog projekta: on je idealno utjelovljivao ključnu ideju jugoslavenskog socijalizma - onu o bratstvu i jedinstvu. Moja je glavna teza u ovome radu da strukturalne razlike između te dvojice junaka počivaju na različitim "izmišljenim tradicijama" (Hobsbawm) te se stoga odnose na različite modele novoga čovjeka. Analizirajući različite tekstove kulture čiji su glavni protagonisti Pavlik Morozov i Boško Buha, istraživanjem ću obuhvatiti nekoliko važnih pitanja. Prvo, u kojoj je mjeri Pavlik Morozov bio poznat u kulturama bivše Jugoslavije te je li on ipak, unatoč raskidu jugoslavenskih diplomatskih veza sa Sovjetskim Savezom 1948., poslužio tadašnjim političkim elitama kao model za proizvodnju jugoslavenskog prototipa mlade žrtve za opće dobro, odnosno za kreaciju novog (sovjetskog i/ili jugoslavenskog) čovjeka u tijelu malenoga dječaka? Drugo, na koje se "izmišljene tradicije" referiraju ta dva modela, i zašto jugoslavenska vlast nije mogla "prenijeti" model Pavlika Morozova u nepromijenjenom obliku u jugoslavenski kulturni diskurs?
\end{abstract}

Ključne riječi: Boško Buha, Pavlik Morozov, novi čovjek, staljinizam, "titoizam"

Jugoslavenskoj je kulturnoj povijesti moguće pristupiti iz niza različitih perspektiva. ${ }^{1}$ Ovaj je rad pokušaj interdisciplinarne analize koja se socijalističkim dijelom njezine prošlosti bavi iz sjecišta sljedećih vizura: filozofske, koja uključuje analizu smisla imagoloških koncepcija i konstrukcija koje su

${ }^{1} \mathrm{U}$ izradi završne verzije ovog rada važne su smjernice dane u sugestijama članice uredničkog tima časopisa te u komentarima dvaju anonimnih recenzenata. Ovom im se prilikom zahvaljujem. 
zaživjele za vrijeme dominacije toga društvenog uređenja; kulturno-povijesne, koja uključuje razradu povijesti ideja (pa će jugoslavenski socijalizam predstavljati razdoblje koje nije bilo obilježeno samo određenim materijalnim nego i imaginativnim, simboličkim praksama); sociološke i politološke, koje uključuju proučavanje društveno-političkih uvjeta koji su stvarali potrebu za određenim tipom simboličkih praksi. Bošku Buhi, vjerojatno najpopularnijem mladom junaku jugoslavenske kulture, pristupit ću kao artefaktu "objektivizirane kulture" čija je funkcija bila stvaranje fiksirane i nepokretne "figure pamćenja" (Assmann 2006) oko koje se strukturirao ratni narativ jugoslavenske kulture sjećanja. Popularnost narativa o Bošku Buhi svjedoči o tome da je za stvaranje jugoslavenskog (nad)nacionalnog identiteta upravo ratni narativ bio presudno važan u stvaranju kolektivne predodžbe (autostereotipa) o vlastitoj posebnosti i specifičnosti.

Odabranoj ću figuri jugoslavenske kulture sjećanja nadalje pristupiti iz komparativne perspektive, što je ponajprije potaknuto tezom o tome da je razvoj jugoslavenskog društvenog uređenja bio bitno određen generativnom povezanošću (u prvim fazama razvoja) te dinamičnim i često ambivalentnim vezama (u kasnijim fazama razvoja) sa sovjetskim modelom socijalizma. Poseban su zamah komparativnom aspektu analize dale neobične sličnosti ikoničke figure jugoslavenskog socijalizma, Boška Buhe, ${ }^{2}$ sa sovjetskim dioskurnim junakom Pavlikom Morozovim, o kojem se danas govori kao o prvom mladom sovjetskom junaku-pioniru čija je priča utjecala na pojedince u različitim slojevima sovjetskoga društva (Kelly 2005: xxv; usp. Družnikov 1995). Porijeklom iz sibirskoga sela Gerasimovka, Morozov je postao poznat po pismu koje je 25. studenog 1931. godine uputio "specijalnim službama" i u kojem je kompromitirao vlastitoga oca, Trofima Morozova, pišući o njegovim vezama s lokalnim bogataškim obiteljima. ${ }^{3}$ Time je u različitim sovjetskim generacijama (do perestrojke i glasnosti u drugoj polovici 80 -ih godina, kada se i u javnome diskursu počelo govoriti o kontradiktornostima, nelogičnostima i brutalnosti njegova postupka, vidi Družnikov 1995; Feldman 1989) slovio kao obrazac "novoga čovjeka" i zorni primjer slijepe odanosti sovjet-

\footnotetext{
${ }^{2}$ Premda u sovjetskoj kulturi postoji niz junaka i junakinja koji se vezuju uz sovjetske borbe u Domovinskom, odnosno Drugom svjetskom ratu, poput Zoje Kosmodem'janske, usporedba upravo ovih dvaju junaka, Pavlika Morozova i Boška Buhe, opravdana je jer je riječ o prvim mladim junacima u sovjetskoj, odnosno jugoslavenskoj kulturi te stoga podupiru moju glavnu polaznu tezu o tome da su se sovjetske i jugoslavenske inačice društveno-političkoga poretka razvijale i temeljile na dvjema različitim idejama. Sovjetski je Savez tako političko-ideološka tvorba nastala kao posljedica ideja izraženih u Oktobarskoj revoluciji, dok je SFRJ, uvjetno govoreći, "ratna tvorba", odnosno država koja je nastala u NOB-u i kao izravna posljedica vrijednosti koje su se ustoličile tijekom toga razdoblja.

${ }^{3}$ O pismima izdaje tijekom 1930-ih u SSSR-u vidi članak Sheile Fitzpatrick "Signals from Below: Soviet Letters of Denunciations of the 1930's" (Poruke odozdo: sovjetska pisma izdaje u 1930-im godinama) (1996).
} 
skoj državi. Ubili su ga, zajedno s 4-godišnjim bratom, rođaci. ${ }^{4}$ Uspoređujući dva mlada junaka pokušat ću odgovoriti na pitanje je li u jugoslavenskom socijalizmu postojala ideja novog homo jugoslavicusa te je li ona - i u kojoj mjeri - bila potaknuta inačicom novog sovjetskog čovjeka, koji je, kao što je poznato, pod nazivom homo sovieticus naširoko primjenjivan u masmedijskim i znanstvenim analizama sovjetskog i ruskog društva nakon istoimene knjige Aleksandera Zinov'eva iz 1982.

Unatoč neizbježno ograničenom analitičkom pogledu koji iznimno heterogeno i često ambivalentno polje jugoslavenske kulturne povijesti socijalizma svodi na homogeno polje koje proizlazi iz arbitrarne "figure pamćenja", smatram da će interdisciplinarna i komparativna vizura pridonijeti prikazu povijesnih, ideoloških i kulturoloških specifičnosti jugoslavenske verzije novog čovjeka: oslanjajući se na živopisni lik Boška Buhe, u radu ću pokušati ocrtati temeljne karakteristike homo jugoslavicusa. ${ }^{5}$

\section{BOŠKO BUHA}

Boško Buha rođen je 1926. u selu Gradini kraj Virovitice. Po uspostavljanju prolazne državnosti u obliku Nezavisne Države Hrvatske (NDH) bio je prisiljen napustiti rodno selo zbog ustaškog terora te se nakon odlaska u srpsku pokrajinu Mačvu pridružio partizanskom pokretu. U Drugoj proleterskoj brigadi bio je vođa bombaškog odjela te se istaknuo kao jedan od najvještijih bombaša. U političkim je krugovima postao poznat nakon što je nastupio na osnivačkom, Prvom kongresu antifašističke omladine Jugoslavije 27. prosinca 1942. u Bihaću, gdje je održao znamenit govor, obilježen nepretencioznošću i neposrednošću: "Ja ću da vam pričam, drugovi, kako mi idemo na bunkere..." (Kačavenda i Živković 1982-1983: 124). Navodno je njegov govor bio stalno prekidan oduševljenim aplauzima slušača, pohvalio ga je sam Josip Broz te mu u znak zahvale poklonio sat (Mikić 1983; usp. Radovanović 1974: 52). Boško Buha je poginuo u 17. godini, 1943., nedaleko od sela Jabuke, "ubivši prethodno nekoliko četnika, koji su ga dočekali u zasjedi, kada se vraćao $\mathrm{s}$

\footnotetext{
${ }^{4}$ Svetlana Boym ističe da je priča o mladome pioniru Pavliku Morozovu "sovjetska verzija mita o Edipu" (Boym 1995: 146), a Orlando Figes navodi da se na vrhuncu popularnosti kulta o Pavliku Morozovu od pionira doslovce "očekivalo da izdajom svoje obitelji dokaže svoju vrijednost" (Figes 2007: 129) te da je nemoguće procijeniti koliko je pionira u praksi slijedilo Pavlikov primjer premda se u sovjetskom tisku stvarao dojam da su tijekom 30-ih godina prošlog stoljeća "seoske sredine bile pune stvarnih pavlika morozova" (isto: 128; usp. poglavlje "Koliko je bilo Pavlika - How Many Pavliks Were There” u studiji Jurija Družnikova Informer 001. Mit o Pavliku Morozovu - Informer 001. The Myth of Pavlik Morozov; vidi i Conquest 1986.; Fitzpatrick 1994).

${ }^{5}$ Tema izgradnje novog socijalističkog čovjeka dosad, koliko mi je poznato, nije bila predmet neposredne analize u pisanjima znanstvenika s područja bivše Jugoslavije. Ipak, u nekolicini se radova ta ideja izrijekom spominje, pa navodim sljedeće: Erdei (2006); Koren (2012); Duraković i Matošević (2013); Duda (2013); Matošević (2013).
} 
omladinske konferencije" (isto: 124). 0 ikoni Narodnooslobodilačke borbe (NOB) i danas na području zemalja bivše Jugoslavije "svi sve znaju". Istodobno, osim po filmu Boško Buha, koji je 1979. godine snimio, usporedno $\mathrm{s}$ istoimenim televizijskim serijalom, poznat i renomiran hrvatski režiser Branko Bauer, nije posve izvjesno kojim je kanalima legenda o Bošku Buhu došla do javnosti i doživjela takvu popularnost.

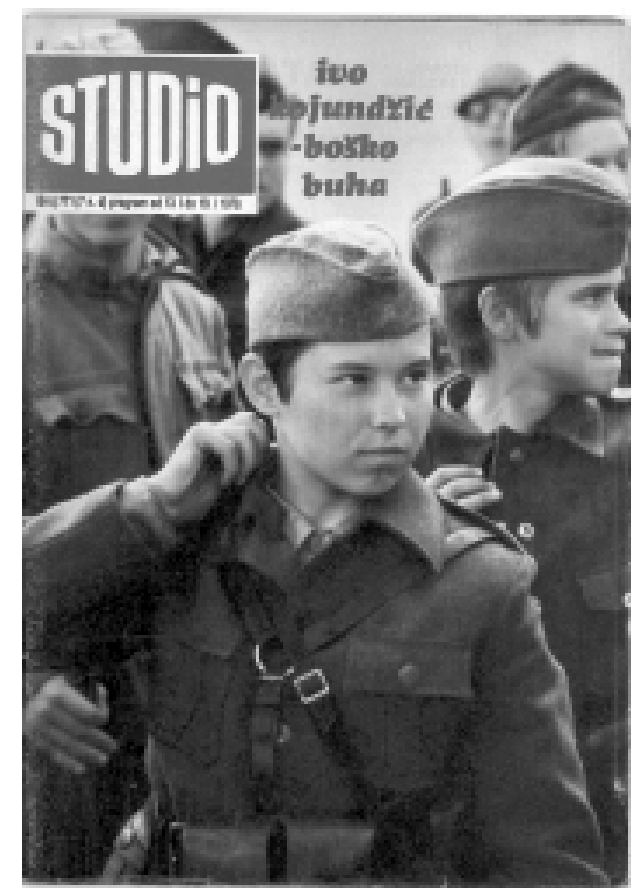

Ilustracija 1. Naslovnica časopisa Studio br. 771. Boško Buha u istoimenom filmu Branka Bauera

Premda su gotovo svi moji sugovornici u neformalnim razgovorima koje sam vodila tijekom istraživanja ove teme od reda znali tko je Boško Buha, mahom su znali i neke detalje iz njegova života te su ih se prisjećali sa zadovoljstvom, većina nije ponudila jasan odgovor na pitanje o tome gdje im je prvi put posredovana legenda o "najpoznatijem bombašu". Uglavnom bi odgovarali neodređeno: "o njemu se govorilo". Zapravo je, kao i u primjeru Pavlika Morozova, riječ o junaku o kojem je ostalo zabilježeno iznimno malo historiografskih podataka te se kolektivno sjećanje oslonilo na niz višemanje proizvoljnih elemenata. ${ }^{6}$ Stoga se o Bošku Buhi može govoriti kao o

\footnotetext{
${ }^{6}$ Jedan je posjetitelj Doma pionira Boško Buha u Jabuci tako napisao sljedeće: "Boško Buha živi u srcima mladih Jugoslavena. Sa svojim bombama, junaštvima, saborcima, životnim porukama. Priča o njemu
} 
kolektivnom simbolu koji je svojim likom i djelom personificirao "izmišljenu tradiciju" (Hobsbawm 1983) uz pomoć koje se strukturirao jugoslavenski politički, ideološki i kulturološki etnicitet.

Moje je istraživanje pokazalo da je upravo osnovnoškolski i srednjoškolski nastavni plan i program, u kojemu se u doba Jugoslavije iznimno puno pozornosti poklanjalo manihejski obrađenoj temi NOB-a, služio kao glavni medij prijenosa legende o Bošku Buhi. Istodobno je školski program bio glavni medij prijenosa homo jugoslavicusa. Naime, u službenim je političkim spisima ideja o novom čovjeku, koji je u jugoslavenskoj inačici nosio naziv "novog socijalističkog čovjeka", prvi put eksplicite izražena u mnogočemu presudnoj Rezoluciji Trećeg plenuma CK KPJ o zaključcima u školstvu, kad je Milovan Đilas, u to vrijeme jedan od vodećih suradnika Josipa Broza, u referatu Problemi školstva u borbi za socijalizam u našoj zemlji, pisao o borbi za izmjenu ljudske svijesti koja treba započeti upravo od "narodne revolucije" i kojom se otvarao put prema izgradnji socijalističkoga društva. Đilas, od 1945. voditelj Odjela za agitaciju i propagandu (Agitprop CK KPJ), nadalje navodi:

Kao veoma važno principijelno pitanje pravca u školstvu postavlja se: Šta mi hoćemo da postignemo, kakvog čoveka težimo da izgradimo? Svima nam je jasno da to treba da bude socijalistički čovek koji voli svoju zemlju i poštuje druge narode, da to treba da bude građanin nove, socijalističke Jugoslavije. To znači da on treba da bude čovjek bogatog unutrašnjeg života, fizički i moralno zdrav, krepak i čio. (istaknula D. L. V.; Đilas 1949: 13)

Upravo su nastavni programi bili najvažniji medij upisivanja ideje o novome čovjeku u tadašnjem jugoslavenskom društvu. Kako navodi Snježana Koren, jedan je od glavnih zadataka obrazovnog sustava bio u stvaranju "'novih ljudi', 'građana socijalističkog društva'" (isto: 9), a komunističke vlasti ocjenjivale su "školski sustav kao jednu od najvažnijih poluga u procesu preobrazbe društva" (isto: 33), o čemu je eksplicite pisao i sam Đilas:

Jedno je, svakako, sigurno: mi treba da vaspitavamo slobodne, socijalističke ljude, ljude koji smjelo i odvažno misle i rade, koji su široki i raznovrsni u shvatanjima, a ne ljude čiji će umovi biti potšišani na isti način (istaknula D. L. V.; isto; usp. Koren 2012: 33).

Posebna je uloga u političkom projektu stvaranja novog čovjeka dana Partiji te, dakako, samom Titu (Đilas 1949: 28), a "borba za novu školu" okarakterizirana je kao "džinovska bitka koju Partija, narodna vlast i narodne or-

postaje sve bogatija, lepša; izvor saznanja, pouka, inspiracija..." (istaknula D. L. V.; prema Radovanović 1974: 89). 
ganizacije vode za izgradnju socijalizma, za izgradnju novog, socijalističkog društva slobodnih ljudi i stvarno ravnopravnih naroda" (isto: 32; usp. izjavu Ive Frola u Koren 2012: 142). Znakovito je da se ideja novog socijalističkog čovjeka u službenom jugoslavenskom političkom diskursu pojavila kao izravna posljedica traumatičnog raskida "bratskog saveza" sa SSSR-om te u tom smislu ideja homo jugoslavicusa nije proizašla iz ideje homo sovieticusa, niti je novi sovjetski čovjek uziman kao prototip, nego upravo suprotno: novi čovjek Jugoslavije nastao je kao iskaz potrebe da se socijalističko društvo Jugoslavije oblikuje u izravnoj opoziciji prema sovjetskome modelu, što je i sam Đilas istaknuo pišući o tome da "[o]čevidno, ni u tom pogledu [odnosno pogledu stvaranja novog čovjeka, nap. D. L. V.] nemamo obrasca na koji bi se mogli u svemu ugledati" (istaknula D. L. V.; Đilas 1949: 13). ${ }^{7}$

Upravo takvo kontekstualno pozicioniranje Boška Buha omogućuje da ga ne promatramo samo kao vojnu legendu, ratnu priču stvorenu u narodu i prenošenu usmenom predajom, nego upravo kao lik koji je tijekom jugoslavenske povijesti inkorporirao neke od ključnih ideja homo jugoslavicusa. Naime, niz sastavnica koje čine image Boška Buhe, i to onako kako je ostao sačuvan u kolektivnom pamćenju, imaju šire, ideološko-povijesno značenje u kontekstu stvaranja ideje o novome čovjeku. Prije svega se to odnosi na stalno naglašavanje njegova malenog rasta u gotovo svim tekstovima kulture posvećenima "liku i djelu" Boška Buhe; zatim na stavljanje diskurzivnog težišta na to da se borio ne samo protiv vanjskih nego i unutarnjih neprijatelja; te, na koncu, na isticanju njegove predanosti ne samo ratnim zbivanjima nego i idejama narodne revolucije, odnosno idejama stvaranja nove Jugo-

\footnotetext{
${ }^{7}$ I inače, kao što je poznato, Josipu Brozu Titu i tadašnjim partijskim čelnicima posebice je teško palo pismo koje su Staljin i Molotov poslali Politbirou CK KPJ 4. svibnja 1948., a u kojem se Crvenoj armiji ne pripisuju samo zasluge za oslobađanje Jugoslavije od okupatora nego se sugerira i da je upravo dolazak sovjetskih snaga omogućio dolazak Komunističke partije Jugoslavije (KPJ) na vlast (Koren 2012: 346). U težnji da učvrste politički položaj KPJ nakon raskida veza sa Staljinom tadašnja je jugoslavenska politička vlast izricala nedvosmislene kritike na račun sovjetskog modela socijalizma (posebice se kritizirao birokratizam i dogmatizam) te je istodobno napravljen važan preokret u prezentaciji NOB-a: ne samo da su se "unosile [...] nove bitke i događaji, veličali heroizam i požrtvovnost partizanskih vojnika, a opisi ofenziva postajali su sve opširniji" (isto: 357), nego je i Narodnooslobodilačka borba izjednačena s pojmom narodne revolucije (to je mjesto do raskida sa SSSR-om zauzimala Oktobarska revolucija). Ipak, kao što je ispravno sugerirao jedan od anonimnih recenzenata prve verzije ovog rada, premda nakon Titova razlaza sa Staljinom dolazi do prekrajanja ratne povijesti i samolegitimacije jugoslavenskog socijalizma, NOB je i tijekom Drugoga svjetskog rata bio prepoznat kao revolucija, o čemu svjedoči niz dokumenata, između ostalog i memoarski zapisi britanskih vojnih misija koje su bile sklone Josipu Brozu i Vrhovnom štabu, koje su govorile o komunizmu i socijalizmu u partizanskom pokretu te su upozoravale na socijalističku budućnost Jugoslavije. Značenje Oktobarske revolucije već je tijekom 30-ih godina bilo diskreditirano te se partizanskom pokretu u NOB-u daje značenje one socijalističke revolucije koja će dovesti do stvaranja novog društvenog poretka. Isto tako, kako je nadalje upozorio anonimni recenzent, partizanske jedinice bile su nezamislive bez političkih komesara koji su bili partijska, a ne vojna funkcija. Na tim važnim i nepravedno zanemarenim kontekstualnim činjenicama zahvaljujem anonimnom recenzentu. Međutim, unatoč spomenutim napomenama, smatram da je specifičnost razdoblja nakon 1948. godine u tome što se tada revolucionarno značenje NOB-a kao političkog, a ne samo ratnim zbivanjima potaknutog pokreta, jasnije i eksplicitnije aktiviralo radi stvaranja jugoslavenskog (nad)nacionalnog identiteta.
} 
slavije. U tome je smislu Boško Buha inkorporirao sva tri tipa "izmišljenih tradicija" o kojima je pisao Eric Hobsbawm (2006). Naime, on je iskorišten kao simbol nacionalno-društvene kohezije nove, "naše" zajednice, jer pripadnost jednom od jugoslavenskih etniciteta u priči o Bošku Buhi nikad nije reprezentirana kao važan aspekt njegove biografije niti kao presudan izvor motivacije u njegovim borbama tijekom NOB-a: za njega su neprijatelji bili svi protivnici jugoslavenske, "naše" ideje. Nadalje, Boško je Buha poslužio kako bi legitimizirao instituciju KPJ te potvrdio status i odnose autoriteta unutar nove države jer je figurirao kao idealan spoj revolucionarne djelatnosti Josipa Broza Tita, odnosno KPJ, i NOB-a. Na koncu, primjer Boška Buhe iskorišten je kako bi se mladima ucijepila uvjerenja, sustav vrijednosti i pravila ponašanja, pa Kamenko Marković u predstavljanju projekta Jugoslavenskog memorijalnog centra Boška Buhe u Gradini piše o tome da je Buha "mladima uzor discipline, hrabrosti i patriotizma. U shvaćanjima mladih, on je legenda i oličenje svih vrlina na kojima se nadahnjuju. Mladi se njime ponose i s njim se poistovjećuju" (Sivački 1980: 1).

\section{“Veliki bombaš manji od puške"}

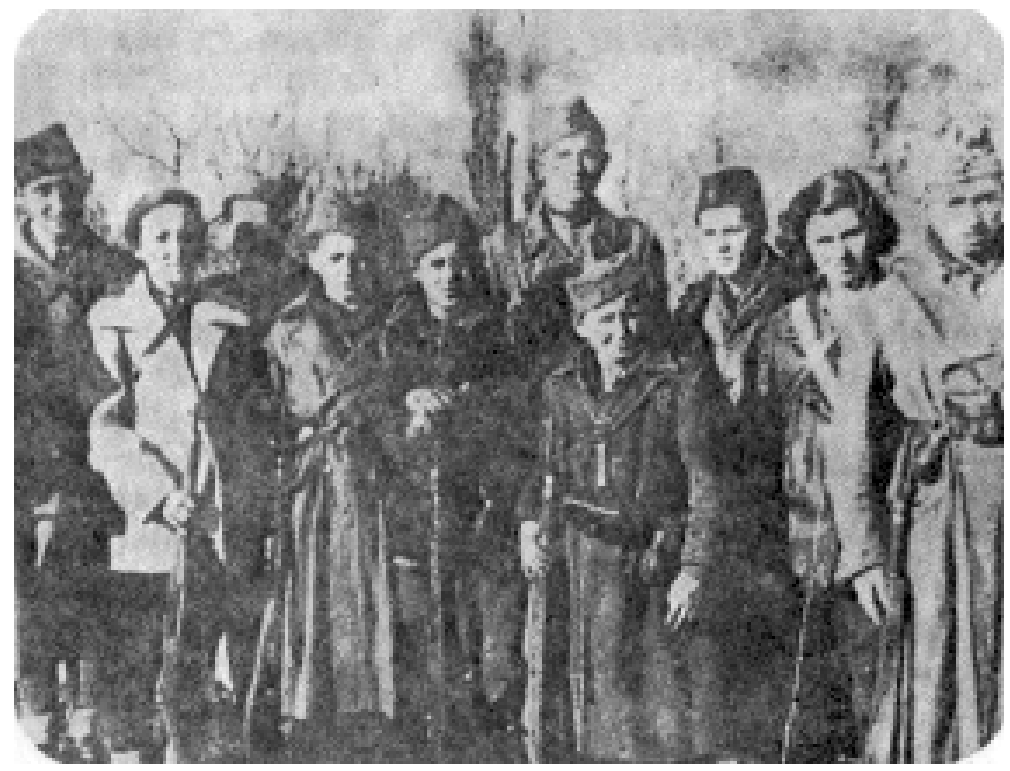

Ilustracija 2. Boško Buha - najniži vojnik (Radovanović 1981: 39)

O Buhinome niskome rastu postoji niz legendi. Jedna od najpoznatijih je da je prije Titova dolaska, a u povodu osnutka Druge proleterske brigade, 
napravio veliku grudu snijega te stao na nju kako bi bio viši, odnosno kako ga zbog niskoga rasta ne bi povukli iz ratnih događanja (Radovanović 1974: 16). U gotovo se svim sačuvanim dokumentima o Bošku Buhi ističe da se na osnivačkome kongresu u Jajcu "nije vidio od govornice" te da je i sam Tito komentirao: "Ti mi, druže, izgledaš suviše mali i slabašan" (isto: 52). ${ }^{8}$ Odabir "naturščika" Igora Kojundžića, umjesto već poznatog mladog glumca Slavka Štimca u naslovnoj ulozi Bauerova filma 1979., također je bio povezan sa Štimčevim previsokim rastom u godini snimanja filma. Upravo je isticanje nesrazmjera između djeteta "manjeg od puške" i velikih, ozbiljnih posljedica njegove bombaške djelatnosti funkcioniralo kao performativni iskaz posebne apelativne vrijednosti čije ishodište možemo naći i u folkloru kultura s područja bivše Jugoslavije, ali i u specifičnom za razdoblje raskida nakon SSSR-a kompetitivnom aspektu razvoja jugoslavenske imagološke misli. Naime, kao što ističe Andrea Matošević u analizi drugog važnog narodnog heroja Jugoslavije, Alije Sirotanovića, kopača iz srednjobosanskog ugljenokopa Breza, neizostavan je dio političke retorike i ideoloških reformi nakon Rezolucije Informbiroa bio u poticanju natjecateljskog duha među jugoslavenskim stanovništvom, a u odnosu na sovjetske dioskurne narodne junake. Matošević ističe:

Lenjin je, kao i naknadno Staljin pod čijim se patronatom "rasplamsao stahanovizam", bio izrazit zagovaratelj socijalističkih takmičenja koja su se u privrednom tkivu jugoslavenskih republika zadržala ipak nešto duže no naklonost Staljinu i Sovjetima. (Matošević 2013: 108)

Popularnost Alije Sirotanovića je, naime, bila upravo u tome što je "1949. za 50 tona premašio rekord tada već proslavljenog kopača iz Donjecka Alekseja Stahanova od 102 tone iskopanog ugljena" (isto: 105). U spomenutom kontekstu razmatranja isticanje malenosti Boška Buhe simbolički je kodirano jer podcrtava važnost dijalektike superiornosti koja je oblikovala jugoslavensku političku misao nakon 1948. i koja je posebice dolazila do izražaja isticanjem nesrazmjera između fizičke malenosti i počinjenih herojskih djela. Maleni Boško Buha ovdje je kolektivni simbol "malenih" (u značenju brojčano inferiornih) jugoslavenskih vojnih snaga, kojima - unatoč brojčanoj inferiornosti - nije bila potrebna pomoć sovjetskih boraca da oslobode

\footnotetext{
${ }^{8}$ Kao što je naglasio jedan od anonimnih recenzenata rada, jedno od općih mjesta u povijesti NOB-a bila je upravo eksplikacija uloge koju su u partizanskim jedinicama imala djeca kao bombaši: bombaši su bili regrutirani iz redova djece-vojnika jer su djeca, zbog sitnijeg stasa, mogla lakše osvajati drukčije neosvojive ciljeve. Maloljetne osobe u partizanskim redovima u tome smislu nisu bile nikakva anomalija. Unatoč tomu, smatram da to što je malenost Boška Buhe postalo jednim od općih i najviše uporišnih mjesta te "figure pamćenja", čime se izdvaja od drugih maloljetnih suboraca time što je "manji od najmanjih", ima dodatno simboličko značenje koje pokušavam osmisliti u pripadajućem odlomku.
} 
jugoslavenske prostore od najezde okupatora tijekom NOB-a. Image Buhe može se iščitavati istodobno i kao pokušaj da se specifikum jugoslavenskog kolektivnog identiteta oblikuje isticanjem da smo "mali, ali hrabri" i kao neposredan odgovor jugoslavenskoga vodstva na pokušaj sovjetskih vlasti da kompromitiraju ulogu domaćih snaga u Drugome svjetskom ratu.

\title{
Boško Buha kao medij za prenošenje idealizirane slike o "našim narodima"
}

\begin{abstract}
"Naše republike otišle su u nacionalizam" - početkom ožujka 1948. upozoravala je Uprava za agitaciju i propagandu (Koren 2002: 95; usp. Sundhaussen 2006: 252, 253 i drugdje). Krajem 50-ih godina isticalo se da "školska omladina u redovnoj nastavi ne upoznaje dovoljno povijest i kulturu drugih naroda Jugoslavije" (Koren 2002: 47). Činjenica da je Boško Buha revitaliziran u kolektivnoj svijesti upravo tijekom 70 -ih godina, i to naručenim filmom o njegovu životu 1975. godine, ${ }^{9}$ uoči ozakonjivanja sustava samoupravljanja 1976. i kada pitanje nacionalizma u federativnim republikama SFRJ postaje
\end{abstract}

${ }^{9}$ Film je naručen na 32. godišnjicu Buhine smrti, odnosno 27. 9. 1975. (Benović 1979: 17; usp. Tomić 1978: 9) i bio je jedinstven po tome što je za njegovu izradu raspisan natječaj na koji se je javilo 14 ljudi. Režiserska je palica uručena Branku Baueru, "istinskom hrvatskom ratnom klasiku” (Knežević 2008: 210), koji se već dokazao i kao autor dječjih i kao autor ratnih filmova (te je dvije teme povezao u rado gledanim serijama Salaš u Malom ritu i Zimovanje u Jakobsveldu, a vjerojatno je najpoznatiji po svojim ekranizacijama istoimenih romana Tone Seliškara Sinji galeb 1953. i Arsena Diklića Ne okreći se, sine 1956). Premda je film Boško Buha bio među omiljenim medijskim štivom tadašnje jugoslavenske mladeži te je bio prikazivan u osnovnim školama kao dio izvannastavnih aktivnosti, a u sklopu edukacije o NOBu, kritičari su pisali o tome da Bauer nije uspio izbjeći "loše nasljeđe naših 'pravljenih' ratnih filmova" (Čelan 1979: 7), isticani su "papirnati” unutarnji konflikti osoba, prikazani teatralnim stiskanjem čeljusti, naglašenim mrštenjima i isforsiranim netremičnim pogledima (isto). Posebice je oštru kritiku požnjela Baureova uporaba tehnike slow motiona na kraju filma, kojom su popraćeni trenuci Buhine pogibije, zbog čega je Nenad Polimac čak izrazio sumnju u "Baureov dobar ukus" (Polimac 1979: 102). Pozitivne su kritike potpisivali mahom novinari koji se nisu profesionalno bavili filmskom kritikom (Benović 1979).

Vrijedi spomenuti da je, u skladu s Lenjinovom krilaticom o filmu kao najvažnijoj od svih umjetnosti i pasioniranim filmofilskim pretenzijama Josipa Broza Tita, u 70-im godinama film nesumnjivo bio jedno od politički najutjecajnijih sredstava masovne komunikacije te je tadašnjim vlastima služio kao zahvalni medij za prenošenje društvenih, odgojnih i obrazovnih poruka (Boglić 1980: 5). Hrvoje Turković je tako pisao da su filmovi bili izdašno financirani iz državne blagajne, a ako bi proizvodnja filma bila zbog ovog ili onog razloga zaustavljena, "problemi su rješavani političkom intervencijom i iz najviših političkih tijela” (Turković 1985: 16). Dvobroj 116/117 časopisa Filmska kritika, tiskan 31. 1. 1979. i posvećen razvoju filma i filmske kritike, započeo je člankom tada istaknute političke osobe Ivice Račana pod nazivom "Društvena potreba a ne puki zbir parcijalnih interesa. Samoupravno organiziranje kinematografije”. U članku Mire Boglić, potaknutom filmovima prikazanima na 26. festivalu jugoslavenskog filma u Puli (26. 7. - 2. 8. 1979.), govori se - u pravom socrealističkom duhu - o tome treba li film biti odraz ili izraz stvarnosti (Boglić 1979: 7-25). Premda je film Boško Buha snimala produkcijska kuća Centar film, sa sjedištem u Beogradu, on je nastao u suradnji s Viba filmom (Ljubljana), Croatia filmom (Zagreb), Kinemom (Sarajevo) te Zeta filmom (Budva), čime se opet simbolički sugerirala ideja da je Buha "naša", zajednička, jugoslavenska ikona. Branko Bauer je nakon Boška Buhe gotovo prestao snimati: godine 1979. snimio je kratkometražni dokumentarni film Samoupravljanje - Nada, zatim 1982. televizijsku emisiju Tito na ratnoj fotografiji i filmu (Titov ratni album) te je iste godine režisersku karijeru (neslavno) završio kratkometražnim, 18-minutnim reklamnim filmom Dubrovnik i rivijera. 
posebno aktualno, podupire tezu da je Boško Buha, između ostalog, bio medij za prenošenje idealizirane slike o "našim narodima", odnosno katalizator ideje o "bratstvu i jedinstvu". Boško Buha se u tome smislu može promatrati kao simbol koji je anticipirao ideju jugoslavenskog socijalističkog patriotizma onkraj nacionalnih granica, za čiji je razvoj i inkorporiranje u službeno političko tkivo također djelomice zaslužan upravo raskid veza sa SSSR-om jer se o njemu govori upravo od prijelaza iz četrdesetih u pedesete godine prošloga stoljeća (podsjećam na referat Đilasa, u kojem se govori o "novoj školi”, "novoj Jugoslaviji", "novom socijalističkom društvu” itd.). Upravo je zbog toga nacionalna "hibridnost", odnosno "izmještenost" Buhina nacionalnog identiteta (odrastao u hrvatskome selu, a porijeklom iz srpske obitelji) imala u političkom smislu nezanemarivo simboličko značenje, koje je naglašavano i time da se Boško Buha nije borio samo protiv tuđinskih ugnjetavača nego i protiv domaćih izdajica, čime se granica "svojih" (Jugoslaveni bez nacionalističkih pretenzija) određivala jasnim omeđivanjem od "njih" (strani, ali i domaći, nacionalizmom zadojeni agresori), a samog se junaka nazivalo nacionalno nespecificiranim odrednicama "slavonsko seljače sa herojskim srcem" (istaknula D. L. V.; Radovanović 1974: 56).

\section{"Prvi bombaš naše revolucije"}

Posebice nakon raskida sa SSSR-om, a kao posljedica Staljinova i Molotovljeva pisma o ulozi Crvene armije u NOB-u, koje je jugoslavenskim političkim elitama poslano u svibnju 1948. (vidi fusnotu 6 u ovome radu), što je posljedično moglo kompromitirati herojsku ulogu jugoslavenskih snaga obrane, $u$ službenim se političkim dokumentima i medijima inzistiralo na tvrdnji da "mi ne bismo izvojevali pobedu da nismo vojnu strategiju stvarali na jasnom političkom programu Komunističke partije Jugoslavije" (Kačavenda, Živković 1982-1983: 9) te su se pojmovi NOB-a i narodne revolucije doveli na istu razinu. Upravo je nakon 1948. godine Josip Broz Tito često isticao "značaj nezavisne izgradnje socijalističkog društva i prava na samostalnost" (isto: 15), što je, kako je sugerirano, "bio najvažniji uslov pobede i u toku narodnooslobodilačkog rata i revolucije" (isto). 0 tome da je Titu bilo osobito stalo da se uspjeh u ratu ne oduzima jugoslavenskim snagama prebacivanjem težišta na ulogu sovjetske vojske te da se zadržavanje autopercepcije jugoslavenskog kao naroda koji je podnio velike žrtve i kojemu zbog toga moraju ostati sve zasluge za izvojevanu pobjedu, svjedoči i povijesno zanimljiv hodogram razvoja institucije narodnog heroja. Naime, premda je zvanje narodnog heroja postojalo od 1943., kada se u kolovozu dodijelio prvi Orden narodnog heroja, i premda je prvim narodnim herojem proglašen Petar Leković još u veljači 1942. godine, najviše je heroja proglašeno upravo nakon Titova raski- 
da svih veza sa Sovjetskim Savezom i nakon što je 1951. potpisan sporazum o vojnoj pomoći SAD-a Jugoslaviji, što je simbolički obilježilo kraj straha od sovjetske invazije te je Jugoslavija zadobila određenu ekonomsku stabilnost (čak je 1091 heroj od ukupno 1322 proglašen od 1951. do 1953. godine, usp. Rihtman-Auguštin 1992; Sundhaussen 2006: 250).

Istodobno, godina 1951. značajna je i po tome što su se tada, sudeći po analizama u studiji Snježane Koren, u jugoslavenskim školama prestali koristiti sovjetski udžbenici iz povijesti. Moguće je da je takav zamah u proglašavanju narodnih heroja od 1951. potaknut, osim željom za učvršćivanjem političke moći tadašnje Komunističke partije Jugoslavije, i željom da se Narodnooslobodilačka borba na području Jugoslavije ispiše u ključu isključivo herojske pobjede jugoslavenskih snaga nad okupatorima, što je posebice relevantno imamo li na umu da je upravo Centralni komitet KPJ imao središnju ulogu u odlučivanju o strateškim ulogama prosvjete, znanosti i kulture (Koren 2002: 32). Odbacivanje sovjetskih udžbenika povijesti nakon Trećeg plenuma CK KPJ utjecalo je i na to da su nove jugoslavenske vlasti morale uspostaviti i definirati novi plan razvoja jugoslavenskoga socijalizma te su za to "morale uspostaviti niz ustupaka nacionalnom diskursu te iznaći način da barem u praksi, ako ne već i u teoriji, inkorporiraju i prilagode nacionalne mitove, sjećanja, vrijednosti, simbole i tradicije" (isto: 132). Upravo se u tom razdoblju stoga revitaliziraju stariji narodni junaci, poput vođe seljačkoga ustanka Matije Gupca, a posebno su mjesto dobili "povijesni likovi koji su na ovaj ili onaj način postali simbolima zbližavanja jugoslavenskih naroda, poput narodnih prosvjetara Ćirila i Metoda ili vladara poput Ljudevita Posavskog i bosanskog kralja Tvrtka kojima se pripisivalo da su svojim djelima na neki način anticipirali zajedničku južnoslavensku državu" (isto: 134). Narodni heroji NOB-a, koji su redovito reprezentirani izvan svojih nacionalnih identiteta, $u$ tom su smislu jugoslavenskim vlastima mogli poslužiti kao polje za osobito uspješnu simboličku kreativnost u ostvarivanju ideje "bratstva i jedinstva", odnosno - težeći uspostavi kontinuiteta s herojskom prošlošću - u stvaranju "izmišljene tradicije" u Hobsbawmovu smislu.

U tom smislu isticanje Buhine važnosti na antifašističkom kongresu u Jajcu na kraju 1942. godine, nakon čega je u javnosti postao sinonim za hrabrost i požrtvovnost, ima dvostruko simboličko značenje: naime, time se prenosila ideja da su herojska djela činili upravo pripadnici jugoslavenskih snaga (prije pomoći stranih, a posebno sovjetskih snaga!) te se istodobno Boško Buha iskorištavao kao neposredni "prošivni šav" između NOB-a i KPJ. On je, uostalom, ostao zapamćen kao "prvi bombaš naše revolucije", odnosno na spomenutom kongresu u Jajcu "nije bio samo delegat Druge proleterske. Bio je utjelovljenje revolucionarnog pokreta mladih, cijele organizacije, Saveza komunističke omladine Jugoslavije" (isto: 124). 


\section{STALJINIZAM VS. “TITOIZAM”}

Ako nam "izmišljene tradicije", kao što je sugerirao Eric Hobsbawm, mogu poslužiti kao simptom i stoga indikator "problema koje možda ne bismo prepoznali i razvoja koje bi inače bilo teško identificirati i datirati" (Hobsbawm 2006: 148), image Boška Buhe u prvi plan ističe tri ključna problema jugoslavenskih političkih elita. Prije svega je riječ o problemu nacionalizma, odnosno pitanja o tome kako da se specifičnosti nacionalnih zajednica, koje su se dotad identificirale s drukčijim sustavom "izmišljenih tradicija", uspješno asimiliraju u (nad)nacionalni, jugoslavenski, "naš" identitet. Potom je riječ o problemu učvršćivanja statusa KPJ kao pionira revolucionarne promjene u duhu marksističko-lenjinističke doktrine, pri čemu se NOB koristila kao glavna platforma koja je legitimirala vrijednost i značenje KPJ. I treće, riječ je o problemu odnosa sa sovjetskim modelom socijalizma, čemu ću posvetiti poglavlje koje slijedi. Naime, na različite se načine u mojoj dosadašnjoj analizi provlačila ideja o tome da je raskid sa SSSR-om 1948. godine imao presudnu ulogu u kreiranju imagološkog repertoara Jugoslavije, pa čak i u tome smislu da se ideja homo jugoslavicusa pojavila usporedno s razočaranjem u ideju homo sovieticusa te u važnim svojim dijelovima kao izravan antipod sovjetskoj inačici, o čemu je pisala i Snježana Koren:

[...] otpor koji je Jugoslavija pružila SSSR-u postao je jedno od važnih uporišta ideologije koja se oblikovala u 1950-ima, preuzevši ono mjesto koje je do tog vremena bilo namijenjeno veličanju SSSR-a i njegovih uspjeha. (Koren 2012: 149)

U tome smislu upravo godinu 1948., prije nego 1943., kad je na Drugom zasjedanju AVNOJA-a 29. studenog, osnovana Demokratska Federativna Jugoslavija, vrijedi promatrati kao kronološku razdjelnicu koja je dala putokaz razvoju ideološke samosvijesti Jugoslavije kao (nad)nacionalne zajednice. Holm Sunhaussen navodi sličnu tezu ističući da se KPJ "za potrebe legitimacije [...] osjetila prinuđena razviti vlastiti model socijalizma, radi razgraničenja prema staljinističkom 'degeneriranom' Sovjetskom Savezu i kapitalističkom Zapadu. To je bio početak jugoslavenskog puta u socijalizam, tj. 'titoizma' kao sustava" (Sunhaussen 2006: 251). Kako onda objasniti zapanjujuće sličnosti između Boška Buhe i sovjetskog dioskurnog junaka Pavlika Morozova? 


\section{Pavlik Morozov i Boško Buha}

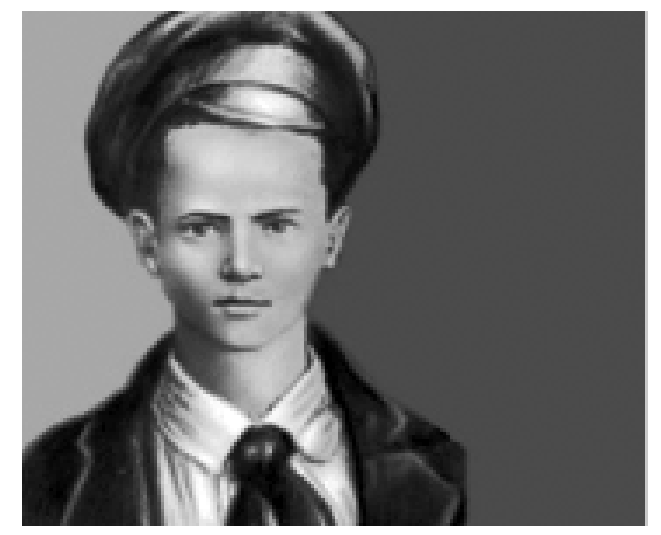

Ilustracija 3. Portret Pavlika Morozova (preuzeto s http://shkolazhizni.ru/ archive $/ 0 / \mathrm{n}-8554 /$ )

Slično kao i u primjeru dioskurnih junaka Stahanova i Sirotanovića, Morozov i Buha zapanjujuće nalikuju jedan na drugoga. Naime, riječ je o modelima mladih junaka-žrtava, koji su bili čak i slične dobi kada su stradali, i to oba nasilnom smrću i iz zasjede. ${ }^{10}$ Postali su popularni zahvaljujući tada utjecajnim članovima političke elite: na Pavlika je upozorio Maksim Gorki, pozivajući tijekom jeseni 1933. na podizanje spomenika mladomu heroju, dok bi Boško Buha vjerojatno ostao posvema nezapamćen da nije sudjelovao na spomenutom osnivačkom kongresu antifašističke omladine u Jajcu 1942., kad ga je pohvalio sam Tito. 0 obojici se učilo u sklopu izvannastavnih školskih aktivnosti. Isto tako, popularnima su postali tek posthumno, što je tadašnjim političkim elitama omogućilo da na njih prislone "kulturu sjećanja". ${ }^{11}$ Dva su junaka prenosila vrlo slične ideje: o požrtvovnosti u izgradnji države i novog sustava te o beskompromisnoj predanosti / odanosti tomu cilju, istodobno svojim životnim putovima sugerirajući da te vrijednosti moraju biti imperativ svakog mladog člana novog društva. I jedan i drugi junak bili su beskompromisni u svojim djelatnostima: Morozovljev čin izdaje oca nije nailazio na univerzalno odobravanje čak ni među njegovim pristašama (vidi Kelly 2005:

\footnotetext{
${ }^{10}$ Kontroverzama povezanima s njegovim ubojstvom detaljno su se bavili Jurij Družnikov u studiji Informer 001. The Myth of Pavlik Morozov - Donosčik 001, ili Voznesenie Pavlika Morozova 1995. i Kelly, C. Comrade Pavlik. The Rise and Fall of a Soviet Boy Hero 2005., vidi također Družnikov 2006.

${ }^{11}$ Jan Assmann u tekstu Kultura sjećanja piše o tome da u kulturi sjećanja prošlost nastaje "tek kada se uspostavi odnos prema njoj" (Assmann 2006: 48) te da "novi počeci [...] dolaze uvijek u obliku povratka prošlosti" (isto: 49). Pritom činjenica smrti često odigrava upravo ključnu ulogu jer "tek s krajem, s radikalnom nemogućnošću nastavka, život dobiva oblik prošlosti na kojoj može počivati kultura sjećanja" (isto: 50).
} 
xxiv), a Branko Bauer je, primjerice, na sljedeći način objašnjavao zašto Boško Buha u istoimenom filmu nije prikazan kao pretjerano simpatičan lik:

Moj osnovni problem, a to naručioci nisu vidjeli, bio je sljedeći. Kazao sam: "Slušajte, ljudi, trideset godina poslije rata mi u filmu moramo naći opravdanje za te dječake, odnosno, ne za njih, nego za odrasle. Ti ne možeš toliko godina poslije rata pokazati da su ta mala djeca bacala bombe, da su ubijala ljude, da su zbog toga postali slavni i da su ih odrasli na sve to podsticali." (Pajkić i dr. 1985: 138)

Nadalje, aktivnosti obojice junaka bile su posljedica dezintegracije obitelji: Morozove je otac napustio zbog druge žene, a tijekom ustaškoga terora u Gradini otac Boška Buhe odlučuje sa sinom napustiti ognjište, ostavljajući pritom iza sebe suprugu: "Žene će ostati, valjda će se nekako snaći, preživeti vojnu oluju" (Radovanović 1974: 5). Možda i kao posljedica raspadanja vlastite obitelji, oba su junaka u vođama naroda - Staljinu, odnosno Titu - vidjela idealnog "zamjenskog oca". Nadalje, oba su javno promovirana u razdobljima u kojima su sovjetsko (1930. godine) i jugoslavensko društvo (početak pedesetih) stvorili "cijelu industriju za proizvodnju junaka" (Kelly 2005: 6). Na koncu, i o jednom i o drugom junaku ne postoji mnogo dokumentiranih podataka, zbog čega su i bili podatni za ideološku i mitotvoračku propagandu. ${ }^{12}$

${ }^{12}$ Interes prema Bošku Buhi u suvremenim je kulturama - što se odnosi i na masovne medije i na akademsku sredinu - s područja bivše Jugoslavije gotovo potpuno nestao. Ipak, u rubrici Junaci Bljeska (naziv Bljesak odnosi se na vojno-redarstvenu akciju hrvatskih snaga obrane, tijekom koje su u svibnju 1995. godine oslobođena okupirana područja zapadne Slavonije, nap. D. L. V.) dnevnik Večernji list prenio je informacije o Nebojši Buhi, nećaku Boška Buhe, koji je s mitraljezom u rukama tijekom rata na hrvatskom području bio hrabar i odvažan kao i njegov stric (Borovac 2013; vidi i Sandić-Hadžihasanović 2013; Koretić). Umjetnica Renata Poljak je u potrazi za junacima svoga djetinjstva nedavno napravila kratkometražni uradak Režiranje glumca / režisiranje uvjerenja (dostupan na http://pogledaj.to/art/cijije-danas-idol-bosko-buha/). U rijetkim se popularnim suvremenim refleksijama na Boška Buhu težište stavlja na dvije dvojbe: 1. je li Boško Buha uopće postojao te 2. “čiji” je bio, odnosno kojoj je nacionalnosti pripadao (vidi Leksikon YU mitologije, http://haw.nsk.hr/arhiva/vol2/786/17710/www.leksikon-yumitologije.net/index.php.html, leksije Bombaši / Partizani-NOB i BOŠKO BUHA / Narodni heroji).

Suprotno tom oskudnom postsocijalističkom životu Boška Buhe, u suvremenoj Rusiji postoji niz znanstvenih i masmedijskih osvrta na kult Pavlika Morozova. Godine 2011. napravljen je multimedijski spektakl Pavlik Moj Bog (vidi http://predateli.net/), godine 2004. snimljen je dokumentarni film Kako su ubili Pavlika ili povijest jednoga mita (Kak ubivali Pavlika ili istorija odnogo mifa, 2006., rež. Grigorij Dikkert; film je dostupan na http://www.youtube.com/watch?v=NGLpyrgK3p4), napisano je nekoliko monografija o njegovu životu i aktivnostima te se o njemu u dnevnom tisku mogu pronaći nizovi kraćih tekstova (vidi primjerice članak o Pavliku Morozovu na http://ru.wikipedia.org/wiki/Морозов_Павел_Трофимович; Savka 2003; Siegelbaum itd.).

Veliki nesrazmjer u suvremenom tretmanu dvaju junaka ima svoje ishodište u načelnim razlikama $u$ tretmanu socijalističke prošlosti u postjugoslavenskom, odnosno postsovjetskom društvu, no razlozi leže i u tretmanu te dvojice junaka u prošlosti. Naime, dok se oko kulta o Pavliku Morozovu tijekom sovjetske povijesti stvorila cijela industrija, koja je uključivala masovne pjesme, knjige, spomenike, opere, filmove - pa i jedan s potpisom Sergeja Ėjzenštejna, a brojne su škole, vrtići, pionirski i omladinski centri, domovi kulture, kazališta, kina, muzeji i druge državne institucije nosile njegovo ime, Boško Buha - premda 
Ipak, unatoč tomu što je poznato da su članovi KPJ koji su kasnije postali vodećim političkim ličnostima poslijeratne Jugoslavije tijekom formativnih, 30-ih godina, često boravili u Sovjetskom Savezu te su "na licu mjesta" upijali mehanizme uvođenja i održavanja socijalističkoga sustava (usp. primjerice Čehov i Marković 1947; Đilas 2009), istražujući ovu temu, nisam naišla na materijalne dokaze koji bi potvrdili da je Boško Buha nastao na "sliku i priliku" Pavlika Morozova (niti, kao u primjeru Sirotanovića i Stahanova, kao posljedica eksplicite izražene kompetitivnosti sa sovjetskim sustavom). ${ }^{13}$ Štoviše, većina mojih sugovornika, uz isključenje onih koji se profesionalno bave sovjetskom i ruskom kulturom, nije znala tko je Pavlik Morozov. Doduše, tijekom 30-ih godina, kad je mit o Pavliku Morozovu službeno normiran, SFRJ nije ni postojala, a krajem 40-ih, kao što sam navodila, prekinuti odnosi sa SSSR-om nisu igrali u korist daljnjem razvoju "bratskih odnosa" sa sovjetskom kulturom. No i unatoč tim, povijesno uvjetovanim otegotnim okolnostima, smatram da je odgovor na pitanje o sličnostima Pavlika Morozova i Boška Buhe u suštini vrlo jednostavan: naime, ideja o novome čovjeku prvi put nije promovirana u sovjetskom socijalizmu (premda nam je danas upravo po sovjetskom modelu najpoznatija), nego u pisanjima Karla Marxa, a u procesu preobrazbe jugoslavenskoga društva koji je uslijedio nakon 1948. jugoslavenske su se političke elite neposredno pozivale upravo na marksističko-lenjinistički, dijalektičko-materijalistički pogled na svijet (Koren 2012: 74). Jugoslavenski model socijalizma tada je zamišljen kao jedini pravi sljedbenik te doktrine, pa je u tome smislu ideja o novome čovjeku povezana kao dio šireg utopijskog projekta izgradnje društva po uzoru na primarni Marxov metatekst. ${ }^{14}$

Premda sam dosad već djelomice odgovorila na pitanje o razlozima razlikovanja sovjetskih i jugoslavenskih "izmišljenih tradicija", postavit ću još jedno, čini mi se, korisno pitanje, čiji se odgovor ne može pronaći bez

su njegovim imenom nazvane različite državne institucije - bio je relativno malo zastupljen u kulturi bivše Jugoslavije: posvećena mu je samo jedna beletrizirana biografija, nekoliko slikovnica te je o njemu snimljen samo jedan film.

${ }^{13}$ Navodno je jednom prigodom Alija Sirotanović, sjedeći ispred rudnika, rekao: “Ovo je ovaj rudnik ovdje, što sam ja pobijedio Stahanova, a Tito Staljina" (Kurspahić) te se njegova pobjeda doživljavala kao Titova pobjeda te istodobno kao pobjeda Jugoslavije nad Sovjetskim Savezom (isto).

${ }^{14}$ Istodobno, osim u marksizmu, ideje o novome čovjeku pojavljivale su se, dakako, u različitim razdobljima te su u različitim društvima često preuzimala slična obličja, pa u tome smislu ne samo novog čovjeka nego i proces "izmišljanja tradicija" uopće valja promatrati kao transnacionalni fenomen. Odjeci ideje o tome da je strukturiranje novog čovjeka neizostavan dio svake političke agende, mogu se vidjeti i u ideji da će se sekularizacija i "pozapadnjivanje" ruskoga društva tijekom vladavine Petra Velikog moći postići brijanjem brade i nošenjem kratkih kaputa u njemačkome stilu, a poznat je primjer ideja stvaranja Nadčovjeka tijekom nacističke vladavine. 0 različitim je aspektima te univerzalne prirode politike sjećanja pisao Etienne François u tekstu "Velike pripovijesti i lomovi brana sjećanja: sjećanje na Drugi svjetski rat između nacionalizacije i univerzalizacije" (2006). Perspektiva promatranja razvoja jugoslavenskog političkog i društvenog tkiva sjećanja u transnacionalnom i transvremenskom kontekstu nudi moguće tumačenje sličnosti između dvaju junaka. 
"pomnog čitanja" sadržaja koji su implicirani dvama junacima: zašto Pavlik Morozov, i da su povijesne okolnosti igrale u "njegovu" korist, nije mogao biti iskorišten za simboličku proizvodnju jugoslavenskog imaginarija, kao što je to bilo sa Stahanovim?

Razlog je opet donekle očigledan: sovjetska i jugoslavenska kultura su u doba stvaranja kulta dvaju junaka bila u drukčijim fazama razvoja socijalističke ideje i društva. Naime, dok je Boško Buha funkcionirao kao medij za izgradnju "izmišljene tradicije" jugoslavenske državnosti na antifašističkoj borbi, NOB-u i, posljedično, na utvrđivanju vodeće političke pozicije KPJ ${ }_{1}^{15}$ do 30-ih je godina - s početkom u Oktobarskoj revoluciji i Lenjinovoj vladavini - sovjetsko društvo već izgradilo temelje "izmišljenih tradicija" te je Staljinovim dolaskom na vlast i učvršćivanjem njegove pozicije vođe već dospjelo u drukčiju fazu svoga razvoja. Poslužimo li se vokabularom Vladimira Papernoga, mogli bismo reći da je Pavlik Morozov produkt kulturno-političkih tendencija Kulture $2{ }^{16}$ koju u svojoj studiji o sovjetskoj arhitekturi ruski povjesničar umjetnosti omeđuje 1932., odnosno 1954. godinom (Papernyj 2007). Kulturu 2 određuje "prijenos vrijednosti u središte" (isto: 20), što se odrazilo i u sve agresivnijim mjerama koje su poticale oslabljivanje veza unutar biološke obitelji i njezinim zamjenjivanjem drugim tipovima društvenih zajednica, poput školskih kolektiva, Komsomola i zajednice pionira te, konačno, političkom legitimacijom ideje o novoj sovjetskoj obitelji na čijem je čelu Veliki Otac Staljin. ${ }^{17}$ U vrijeme političkog i ideološkog strukturiranja Jugoslavije, kad je revitalizirano značenje Boška Buhe, jugoslavenska je kultura tek počinjala - legitimirajući raskidom od SSSR-a policentričnost

${ }^{15}$ Holm Sundhaussen navodi da su "Drugi svjetski rat i druga Jugoslavija, njezini utemeljitelji i utemeljujući mitovi bili neraskidivo vezani”, da su "polazne točke i sidrište druge Jugoslavije ostale [...] godine 1941-1945" te da je "iskustvo rata bilo [...] polazna točka i sidrište jugoslavenskog identiteta" (Sundhaussen 2006: 243, 245).

${ }^{16}$ U svojoj studiji Kultura Dva (Kul'tura Dva, Ann Arbor 1985; Moskva 1996, 2006, 2007) ruski američki povjesničar umjetnosti, analizirajući sovjetsku arhitekturu iz strukturalističke metodološke prizme i sugerirajući da su stvaralačke prakse suptilno i često skriveno isprepletene s ideološkim trendovima, opisuje sovjetsku svakodnevicu kroz dva konceptualna modela: Kulturu 1 i Kulturu 2. Kulturu 1 Papernyj vezuje uz prvo razdoblje sovjetske povijesti (do 1932. godine) te je definira kao "horizontalni", otvoreni tip kulture kojim je dominirala težnja prema novomu (ruska avangarda). Kultura 2 se vezuje uz kasnije razdoblje sovjetske povijesti (1932.-1954.) te je obilježena "vertikalnošću", zatvorenošću, podizanjem granica i okretanjem prema prošlosti. U umjetnosti, arhitekturi i dizajnu tendencije Kulture 1 ilustriraju konstruktivisti, dok se Kultura 2 vezuje uz pompozniji stil neoklasicizma. Konceptualni modeli Kulture 1 i Kulture 2 primjenjivi su, po sudu Papernog, ne samo za opis sovjetske kultura Stalinova, odnosno Leninova vremena. Kulturu 1 Hruščëvljeve odjuge (rus. ottepel') zamijenila je Kultura 2 Brežnjevljeve stagnacije u 70-im godinama itd.

${ }^{17}$ U Sovjetskom su Savezu, kao posljedice velike gladi početkom 20-ih godina, postojali milijuni siročadi koji su mogli, ako se odmetnu kontroli političkih vlasti, bitno destabilizirati sustav. Istraživanja su pokazala da je kult o Pavliku Morozovu upravo tu populaciju vidio kao svoju ciljanu publiku (Figes 2007: 125). Upravo je za siročad blistav i slavljen primjer Pavlika Morozova poslužio kao ilustracija ideje da biološka obitelj nije jedino autoritativno društveno okružje, dok je ostale mladiće i djevojke ohrabrivao da se odcijepe od svojih roditelja te pridruže velikoj sovjetskoj obitelji. 
“'svjetskog komunizma”" (Sundhaussen 2006: 251) - svoj politički i ideološki put, određivala je smjernice daljnjeg razvoja te je time strukturalno bila bliža Kulturi 1 kao prethodnici Kulture 2. Jugoslavija je tada prolazila kroz inicijalnu legitimizaciju države i režima, gdje je središnje mjesto zauzimao upravo proces "oživljavanja žrtava podnesenih za pobjedu" (isto: 247).

U tome je kontekstu važno naglasiti i da se ni sovjetski projekt izgradnje novog čovjeka nije rasplamsao neposredno nakon Oktobarske revolucije i tijekom Lenjinove vladavine, nego upravo početkom 30 -ih godina, tijekom kolektivizacije, kada su sovjetske političke elite posebice opasnog neprijatelja pronašle unutar redova samog sovjetskog društva te kad je sukob između starog (kulaci, aristokracija i drugi neprijatelji sustava) i novog (nova proleterska klasa, radnici) zahtijevao posebno strogi nadzor tadašnjih političkih elita. Tada su Staljinovi potezi preobrazbe sovjetskog društva počeli vrlo agresivno zadirati u same njegove temelje: seljaštvo i obitelj. Dvije su radikalne ideje oblikovale odnos prema seljaštvu i obitelji: 1 . da pripadnost klasi nije nepromjenjiva i fiksna kategorija te 2 . da se identitet pojedinca vezuje isključivo uz njegov odnos prema državi.

Obje su ideje bitno utjecale na načine konstruiranja tkiva kulta o Pavliku Morozovu. Naime, budući da se cilj prvog petogodišnjeg plana prezentirao kao kult osobnog uspjeha, sovjetska je propaganda poticala društvenu mobilnost i napuštanje "porijeklom nametnute" sudbine: "sinovi i kćeri radnika poticani su da steknu više obrazovanje, seljačka djeca sanjala su o dolasku u gradove" (Figes 2007: 131). Posebice podatnima za napuštanje "prokletstva" vlastite klase bili su upravo potomci kulaka, među kojima je navodno bio i Pavlik Morozov, i drugih neprijatelja sovjetskog režima: "Odrastajući sa stigmom svojega porijekla, oni su htjeli da ih se prepozna kao ravnopravne članove društva, što su mogli postići jedino raskidajući sve veze sa svojom prošlošću" (isto). Kao i potomci aristokratskih obitelji, i djeca kulaka su se često upravo činom distanciranja od vlastitih bioloških obitelji dokazivala kao odani sovjetski građani.

O obitelji se u 30-im godinama govori kao o "temeljnome obliku ropstva" (Kaganovsky 2008: 74) te se predviđa njezin konačni kraj, a kao što je argumentirao ideju o podizanju spomenika Pavliku Morozovu, sam Maksim Gorki sovjetski je junak "shvatio da biološki srodnik može biti neprijatelj duha te da takvu osobu ne treba štedjeti" (prema Figes 2007: 124). U tome se smislu ideja o novome sovjetskom čovjeku u 30-im godinama ispreplela s idejom nove sovjetske obitelji (Boym 1995: 146; Günther 2000) za čiji opstanak biološke veze nemaju baš nikakvo značenje. Činjenica da je Pavlik Morozov promoviran u priči koja uključuje obiteljske odnose sugerira edipsku strukturu toga mita, pri čemu je priču o Bošku Buhi nemoguće interpretirati u tim intertekstualnim i psihoanalitičkim okvirima. Ishodno iz spomenutih bitnih strukturalnih razlika i sukladno napomeni anonimnog recenzenta, daljnja 
razrada ovog rada mogla bi uključivati tezu da je Buha revolucionar točno na mjestu gdje Morozov to nije i ne može biti, odnosno na mjestu gdje je Morozov čak kontrarevolucionaran. ${ }^{18}$

Iz tih perspektiva biva jasnijim odgovor na postavljeno pitanje. Naime, Pavlik Morozov, i da su povijesne okolnosti igrale u "njegovu" korist, nije mogao biti iskorišten za simboličku proizvodnju jugoslavenskog imaginarija zbog toga što su tadašnji društveno-politički uvjeti stvarali potrebu za drukčijim tipom simboličke prakse. Naime, Boško Buha poslužio je uspostavljanju kontinuiteta s herojskom prošlošću NOB-a i pritom nije bio neposredan nositelj problema povezanih s klasnom neravnomjernošću i klasnim pitanjem, dok je Pavlik Morozov posljedica Staljinova političkoga plana koji se u biti svodi na radikalni diskontinuitet, tj. prekid s ključnim društvenim institucijama predsovjetske Rusije - seljaštvom i obitelji, pri čemu se potonja društvena institucija u sovjetskoj verziji Nove Obitelji u mnogome strukturirala kroz edipalne odnose. Pavlik Morozov je u tom smislu utjelovio potrebu tadašnjih sovjetskih političkih vlasti da se - zadirući u ta dva kamena-temeljca tradicionalne ruske kulture - obračunaju s "klasnim neprijateljima", konačno riješe "klasno pitanje" i nametnu se kao krajnja (a ne početna, kao što je bilo s Jugoslavijom u to doba) točka razvoja sovjetskoga društva.

\section{EPILOG}

S obzirom na to da prisutnost Pavlika Morozova u tekstovima suvremene ruske kulture i u radovima znanstvenika iz humanističkih i društvenih znanosti ne samo u Rusiji nego i u svijetu ne jenjava, njegov je kult - kada to već nije uspjelo Sovjetskom Savezu - doživio manje ili više "svijetlu budućnost". Mlada ikona jugoslavenske kulture nije bila te sreće. Vihor poginulih, nestalih, prognanih i izbjeglih građana bivše Jugoslavije tijekom ratova od 1991. do 1995. progutao je i narativ o njemu te je Buha nastavio živjeti, kao i druge, "nepoćudne" žrtve novih sustava država koje su se nekad pozivale na "bratstvo i jedinstvo", u nasumičnom pamćenju varljive nostalgije. U hrvatskoj

\footnotetext{
${ }^{18}$ Poznato je da se je Stalin ubrzo nakon dolaska na vlast, a posebice u 30-im godinama 20. stoljeća odmetnuo od Leninovih ideja o ulozi Komunističke partije u revolucionarnoj izgradnji društva. Naime, po Leninovoj inicijalnoj ideji, marksizam ne negira važnost uloge lidera radničke klase, no istodobno ne odobrava poteze lidera koji će od njega stvoriti "vođu", a od naroda bezobličnu "masu". Upravo je to otuđenje od inicijalnih Leninovih ideja implicirano i u primjeru Pavlika Morozova - kontrarevolucionarnost toga mita sadržana je u tome što reprezentira i odzrcaljuje početke Staljinove aktivnije usmjerenosti na isticanje svoje uloge vođe, odnosno na kreiranje onoga što će Hruščëv - pod nazivom kulta ličnosti - žestoko iskritizirati na 20. sjednici Komunističke partije 1956. S druge strane, Boško Buha je upravo, kao što smo pokazali u ranijim dijelovima rada, zbog svoga sudjelovanja u pokretu potlačenih masa (bio je potomak siromašnoga seljaka) protiv “imperijalističkih okupatora” tijekom NOB-a bio percipiran kao utjelovljenje revolucionarnog pokreta Saveza komunističke omladine Jugoslavije.
} 
masovnoj kulturi 21. stoljeća narodni je junak preimenovan u Boška Buku te je u reklami za Ožujsko pivo pretvoren u pivopiju ${ }^{19}$ koji, kao i Žuja, kao glavni označitelj reklame te "jedino pivo s nadimkom", nosi nadimak legendarnog bombaša jer "najbolji prijatelji iz srednje uvijek imaju nadimke". Oskudni postsocijalistički život Boška Buhe ne svjedoči samo o tome da je na području bivše Jugoslavije socijalizam još jedna u nizu "nepoćudnih tema" nego i o tome da su ideologije nepostojane kao i tragovi u snijegu. Ipak, premda Jugoslaviju, njezino političko i društveno uređenje i "figure pamćenja" koje su oblikovale kulturu sjećanja i izmišljale tradiciju često zanemaruju oni koji su je proživjeli kao odrasli građani, u suvremenoj hrvatskoj humanistici postoji niz istraživača mlađe generacije koji su jugoslavenski socijalizam živjeli kao pioniri i omladinci te su ga promatrali iz perspektive školskih klupa (tim je nazivom, Socijalizam na klupi, naslovljen i zbornik objavljen 2013., odnosno znanstvena konferencija održana u Puli u prosincu iste godine). Na Sveučilištu Jurja Dobrile u Puli prije nekoliko je godina osnovan Centar za kulturološka i povijesna istraživanja socijalizma, prijavljuju se projekti i pišu znanstveni radovi i studije o nasljeđu jugoslavenskog socijalizma, što svjedoči o tome da zanimanje za (jugo)refleksiju svakako postoji.

Budući da i ja pripadam generaciji "vječnih pionira", ovim sam radom - promatrajući Boška Buhu "iz klupe" - mladog junaka posthumno vratila tamo gdje je u prvom redu oduvijek i trebao biti: u školsku klupu.

Ipak, u pokušaju da odgovori na neka pitanja, ova je analiza otvorila niz novih tema. Naime, osim službenog i javno promoviranog narativa o Bošku Buhi, kojim sam se bavila u ovom radu, postoji i njegov zanemareni i utoliko analitički posebice intrigantni dio. "Sekundarni" dijelovi narativa ponajprije se vezuju uz provokativnu tezu da Boško Buha, progonjen od ustaša i ubijen od četnika, svjedoči o tome da je službeni historiografski narativ o NOB-u (u kojem partizani i nacisti / fašisti slove kao jedini dobri, odnosno loši momci) problematično simplificiran na samo dvije suprotstavljene strane. Nadalje, tijekom 1990. i 1991. godine u prostorijama je beogradskog dječjeg kazališta "Boško Buha" tijekom večernjih sati bila diskoteka koja se je popularno nazivala "Buhom". Ta je društvena praksa utoliko začudna i bizarna - posebice u kontekstu osvita patrijarhalnih i nacionalistički usmjerenih kultura Jugoslavije uoči njezina raspada - ne samo zbog toga što je noćni klub djelovao u sklopu dječjeg kazališta nego i zbog toga što se četvrtkom održavala rado posjećivana večer namijenjena homoseksualnoj populaciji. Spomenuta dva zanemarena dijela narativa o Bošku Buhi svjedoče o potrebnoj reviziji ne samo historiografskog narativa nego i o tome da fiksirane i nepokretne "figure pamćenja" u trenutku iskoraka iz povijesnih udžbenika te iz službene u popularnu kulturu gube svoju fiksiranost i nepokretnost.

\footnotetext{
${ }^{19} \mathrm{http}: / /$ www.youtube.com/watch?v=xZM4TxhzDIk.
} 


\section{NAVEDENA LITERATURA I IZVORI}

Assmann, Jan. 2006. “Kultura sjećanja”. U Kultura pamćenja i historija. Maja Brkljačić i Sandra Prlenda, ur. Zagreb: Golden marketing-Tehnička knjiga, 47-78.

Benović, Maja. 1979. “Bombaš, naravna stvar!” Studio 771: 16-17 (13. 1. - 19. 1. 1979.).

Benović, Maja. 1979. “Razgovor s ratnim drugovima Boška Buhe”. Studio 772: 14-15 (20. - 26. 1. 1979.).

Boglić, Mira. 1979. “Odraz ili - izraz stvarnosti?” Filmska kritika 116/117: 7-25 (31. 1. 1979.).

Bombaši. Leksikon Yu mitologije. Dostupno na: http://haw.nsk.hr/arhiva/vol2/786/17710/ www.leksikon-yu-mitologije.net/read.php\%3fid\%3D550.html (pristup 11. 4. 2014.).

Borovac, Marina. 2013. “Nećak Boška Buhe od mitraljeza Gare nije se htio odvojiti”. Dostupno na: http://www.vecernji.hr/hrvatska/necak-boska-buhe-od-mitraljeza-gare-nije-se-htioodvojiti-546638 (pristup 11. 4. 2014.).

Boško Buha. Leksikon Yu mitologije. Dostupno na: http://haw.nsk.hr/arhiva/vol2/786/177 10/www.leksikon-yu-mitologije.net/read.php\%3fid\%3D1046.html (pristup 11. 4. 2014.).

Boym, Svetlana. 1995. "From the Russian Soul to Post-Communist Nostalgia". Representations. (Special Issue: Identifying Histories: Eastern Europe Before and After 1989) 49: 133-166.

Conquest, Robert. 1986. Harvest of Sorrow. The Harvest of Sorrow: Soviet Collectivization and the Terror-Famine. Oxford: Oxford University Press.

Čehova, Mira i Miroslav Marković, prev. Susreti sa Staljinom. Beograd: Kultura.

Čelan, Joško. 1979. “Boško Buha”. Slobodna Dalmacija, 13. 3. 1979: 7.

Družnikov, Jurij. 1995. “Donosčik 001, ili Voznesenie Pavlika Morozova”. Dostupno na: http:// www.druzhnikov.com/text/rass/donos/ (pristup 12. 4. 2014.).

Duda, Igor. 2013. “Djeca socijalističke domovine. Izgrađivanje pionirske tradicije u Hrvatskoj 1950-ih godina”. U Socijalizam na klupi. Jugoslavensko društvo očima postjugoslavenske humanistike. Lada Duraković i Andrea Matošević, ur. Pula, Zagreb: Srednja Europa, Sveučilište Jurja Dobrile u Puli, Sa(n)jam knjige u Istri, 77-101.

Duraković, Lada i Andrea Matošević. 2013. "Uvodna riječ urednika”. U Socijalizam na klupi. Jugoslavensko društvo očima postjugoslavenske humanistike. Lada Duraković i Andrea Matošević, ur. Pula, Zagreb: Srednja Europa, Sveučilište Jurja Dobrile u Puli, Sa(n)jam knjige u Istri, 11-15.

Đilas, Milovan. 1949. "Problemi školstva u borbi za socijalizam u našoj zemlji". Savremena škola 4/8-10: 7-32.

Đilas, Milovan. 2009. Vlast i pobuna. Zagreb: EPH, Liber.

Erdei, Ildiko. 2006. “Odrastanje u poznom socijalizmu - od 'pionira malenih' do 'vojske potrošača”'. U Devijacije i promašaji. Lada Čale Feldman i Ines Prica, ur. Zagreb: Institut za etnologiju i folkloristiku, 205-240.

Feldman, Jan. 1989. "New Thinking About the 'New Man'. Developments in Soviet Moral Theory", Studies in Soviet Thought 38/2: 147-163. [http://dx.doi.org/10.1007/BF00838102]

Figes, Orlando. 2007. The Whisperers. Private Life in Stalin's Russia. New York: Metropolitan Book.

Fitzpatrick, Sheila. 1994. Stalin's Peasants. Resistance and Survival in the Russian Village after Collectivization. Oxford: Oxford University Press.

Fitzpatrick, Sheila. 2000. Everyday Stalinism. Ordinary Life in Extraordinary Times. Oxford: Oxford University Press. 
François, Etienne. 2006. "Velike pripovijesti i lomovi brana sjećanja. Sjećanje na Drugi svjetski rat između nacionalizacije i univerzalizacije”. U Kultura pamćenja i historija. Maja Brkljačić i Sandra Prlenda, ur. Zagreb: Golden marketing-Tehnička knjiga, 221-237.

Günther, Hans. 2000. "Arhetipy sovetskoj kul'tury”. U Socrealističeskij kanon. Hans Günther i Evgenij Dobrenko, ur. Sankt-Peterburg: Akademičeskij proekt, 743-784.

Haynes, John. 2003. New Soviet Man. Gender and Masculinity in Stalinist Soviet Cinema. Manchester: Manchester University Press.

Hobsbawm, Eric. 2006. "Izmišljanje tradicije”. U Kultura pamćenja i historija. Maja Brkljačić i Sandra Prlenda, ur. Zagreb: Golden marketing-Tehnička knjiga, 139-150.

Kačavenda, Petar i Dušan Živković. 1982-1983. Narodni heroji Jugoslavije. Beograd, Titograd: Partizanska knjiga, Narodna knjiga, Pobjeda.

Kaganovsky, Lilya. 2008. How the Soviet Man was Unmade. Cultural Fantasy and Male Subjectivity Under Stalin. University of Pittsburgh Press.

"Kak ubivali Pavlika ili istorija odnogo mifa". Dostupno na: http://www.youtube.com/ watch?v=NGLpyrgK3p4 (pristup 11. 4. 2014.).

Kelly, Catriona. 2005. Comrade Pavlik. The Rise and Fall of a Soviet Boy Hero. London: Granta Books.

Knežević, Luka. 2008. “Hrvatski filmaši i diverzanti”. Re (Rijeka) 8/14: 206-211.

Koren, Snježana. 2012. Politika povijesti u Jugoslaviji: 1945-1960. Komunistička partija Jugoslavije, nastava povijesti, historiografija. Zagreb: Srednja Europa.

Koretić, Dora. "A gdje su sada Boško Buha i smogovci?” Dostupno na: http://globus.jutarnji. hr/zivot/a-gdje-su-sada-bosko-buha-i-smogovci (pristup 11. 4. 2014.).

Kurspahić, Ajla. “Alija Sirotanović, junak Titovog doba”. Dostupno na: http://novinar.me/index.php/moj-heroj/item/845-alija-sirotanovic-junak-titovog-doba (pristup 11. 4. 2014.).

Matošević, Andrea. 2013. "Politika rada Pokreta za visoku produktivnost". U Socijalizam na klupi. Jugoslavensko društvo očima postjugoslavenske humanistike. Lada Duraković i Andrea Matošević, ur. Pula, Zagreb: Srednja Europa, Sveučilište Jurja Dobrile u Puli, Sa(n)jam knjige u Istri, 105-123.

Mikić, Aleksa. 1983. Boško Buha. Sarajevo: Veselin Masleša.

Pajkić, Nebojša. Nenad Polimac, Hrvoje Turković i Zoran Tadić. 1985. “Intervju s Brankom Bauerom". U Branko Bauer. Slobodan Šnajder, ur. Zagreb: Cekade, 7-27.

Papernyj, Vladimir. 2007. Kul'tura Dva. 2-e izdanie. Moskva: Novoe literaturnoe obozrenie.

"Pavlik, Moj Bog". Dostupno na: http://predateli.net/ (pristup 11. 4. 2014.).

"Pavlik Morozov". Dostupno na: http://ru.wikipedia.org/wiki/Морозов_Павел_Трофимович (pristup 11. 4. 2014.).

Polimac, Nenad. 1979. “Boško Buha”. Pitanja, travanj 1979: 102-103.

Radovanović, Jovan. 1974. Boško Buha. Veliki bombaš manji od puške. Gornji Milanovac: Dečje novine.

Radovanović, Jovan. 1981. Boško Buha. Životni put slavnog bombaša. Gornji Milanovac: Biblioteka "Legende".

Sandić-Hadžihasanović, Gordana. 2013. "Filmovi našeg djetinjstva. Odrastanje uz 'Boška Buhu' i 'Vlak u snijegu'”. Dostupno na: http://www.slobodnaevropa.org/content/filmovi-naseg-djetinjstva-od-boska-buhe-do-vlaka-u-snijegu/24910564.html (pristup 11. 4. 2014.). 
Savka, Ol'ga. 2003. "Soviet Hero Pavlik Morozov Still Mysterious”. Dostupno na: http://english.pravda.ru/history/23-09-2003/3770-morozov-0/ (pristup 10. 4. 2013.).

Siegelbaum, Lewis. "Pavlik Morozov. Seventeen Moments in Soviet History". Dostupno na: http://soviethistory.macalester.edu/index.php?page=subject\&SubjectID=1934pavlik\&Ye ar=1934 (pristup 10. 4. 2014.).

Sivački, Jovan. 1980. Jugoslavenski Memorijalni centar "Boško Buha” u Gradini. Virovitica: Odbor za izgradnju jugoslavenskoga Memorijalnog centra "Boško Buha".

Sundhaussen, Holm. 2006. "Jugoslavija i njezine države sljednice. Konstrukcija, destrukcija i nova konstrukcija 'sjećanja' i mitova”. U Kultura pamćenja i historija. Maja Brkljačić i Sandra Prlenda, ur. Zagreb: Golden marketing-Tehnička knjiga, 241-284.

Šaša, Milan. 1989. Kotar Virovitica u narodnooslobodilačkom ratu. Virovitica: SUBNOR, OK SKH.

Tomić, Branko. 1978. “Buhino srce i u ovoj generaciji kuca”. Oslobođenje, 24. 12. 1978: 9.

Turković, Hrvoje. 1985. "Karijera na prijelomu stilskih razdoblja. Interpretacija Bauerove karijere". U Branko Bauer. Slobodan Šnajder, ur. Zagreb: Cekade.

Turković, Hrvoje. 2002. (1985). "Branko Bauer. Karijera na prijelomu stilskih razdoblja". Hrvatski filmski ljetopis 8/30: 8-28.

\section{THE NEW (YUGOSLAV / SOVIET) MAN IN A LITTLE BOY'S BODY: BOŠKO BUHA AND PAVLIK MOROZOV}

\section{SUMMARY}

Pavlik Morozov and Boško Buha are the first young heroes-victims in Soviet and Yugoslav cultures respectively, who can be seen as models in the process of construing the New Man. These two New Men in little boys' bodies surprisingly resemble each other on several levels, ranging from visual representation to the articulation of their life paths in cultural texts. Both of them were brave underage fighters coming from rural regions who perished due to their loyalty to ideological regimes, thus becoming victim-idols used by the political elites for the purposes of political manipulation. However, whereas Morozov served as an ideal model for the articulation of different Soviet ideas of the New Man, the image of Buha was a consequence of an entirely different political project and embodied one of the key ideas of the Yugoslav socialism: the one of fraternity and equality. This paper deals with several relevant questions by observing Pavlik Morozov and Boško Buha as "figures of memory" (Assmann 2006) that had a strong mnemonic energy throughout the Soviet and Yugoslav socialist pasts. Firstly, how well known was Morozov in the cultures of the former Yugoslavia and did he serve the political elites as a model for the production of a Yugoslavian prototype of a young sacrifice for the greater good, i.e. for the creation of a (Soviet and/or Yugoslav) New Man in a little boy's body even in spite of Tito's "No" to Stalin? Secondly, which "invented traditions" (Hobsbawm) do these two models refer to and why was the Yugoslav government unable to "transfer" the model of Morozov in an unaltered form into the Yugoslav cultural discourse?

Key words: Boško Buha, Pavlik Morozov, New Man, Stalinism, “Titoism” 